\title{
Validity and Reliability Evidence of Professional Obsolescence Scale According to Different Test Theories
}

\section{Sadegul Akbaba Altun (iD), Sener Buyukozturk (D)2, Merve Yildirim Seheryeli (iD),}

\author{
${ }^{1}$ Başkent University, Faculty of Education, Department of Educational Sciences, Division of Educational \\ Administration, Ankara, Turkey \\ ${ }^{2}$ Hasan Kalyoncu University, Faculty of Education, Department of Educational Sciences, Division of Educational \\ Measurement and Evaluation, Gaziantep, Turkey
}

\section{ARTICLE HISTORY}

Received: Aug. 27, 2020

Revised: Feb. 06, 2021

Accepted: Mar. 03, 2021

Keywords:

School principals,

Professional obsolescence,

Scale development,

Professional development activities.

\begin{abstract}
This study aims to develop a scale that will determine the factors causing professional obsolescence in the field of education. In this context, the Professional Obsolescence Scale (POS) has been developed to determine the professional and organizational obsolescence of primary, secondary and high school administrators. In this scale development process, steps were followed in line with the suggestions of Crocker and Algina (2006) and Cronbach (1984). Firstly, 63 items were prepared and 991 school principals participated the study. $\mathrm{R}$ (version 4.0.1) software was used to analyze the data. Item and test parameters and information functions have been estimated using Samejima's Graded Response Model based on Item Response Theory. Principal Axis Analysis was performed for the construct validity of the scale, and four-dimensions structure with 47 items has been obtained. These dimensions are named as "Being Open to Professional Development", "Job-Ability Harmony in Profession", "Organizational Support in Professional Development", "Professional Burnout". The scores obtained from each dimension are evaluated within themselves. It has been observed that each dimension fulfills the conditions of unidimensionality, local independence, model-data fit and parameter invariance. According to the Classical Test Theory, Cronbach Alpha coefficients are between 0.807 and 0.945 . The Stratified Alpha coefficient calculated for the whole scale is 0.94 . According to the Item Response Theory, the marginal reliability coefficients were between 0.857 and 0.936 and the empirical reliability coefficients were found between 0.854 and 0.938 .
\end{abstract}

\section{INTRODUCTION}

The concept of "Eskimişlik" is used as "Obsolescence" in English. In this context, it is generally explained as the concepts of professional or managerial obsolescence in studies related organizations. The Turkish Language Institute (TLI) dictionary does not represent the concept of "eskimişlik (Obsolescence)". However, it explains the concepts of old, obsolescence, aging and becoming outdated. The word "eski (old)" as an adjective covers expressions such as "long-

\footnotetext{
*CONTACT: Merve YILDIRIM SEHERYELI \yldrm.mrv.7806@gmail.com Hasan Kalyoncu University, Faculty of Education, Department of Educational Sciences, Division of Educational Measurement and Evaluation, Gaziantep, Turkey
} 
standing, long-gone, anti-new, previous, non-valid, long-time working in any profession, specialized in the profession, experienced". Again, as a name form for the word "old", there are expressions of "a thing worn out, ruined, a word used in cases in which a person does not have his old respectability because he has lost his position or lost his status". While the name form for the word "aging" is specified as "aging work"; to explain the word getting old, there are expressions such as "to become old, to be worn out, to be disgraced, to be worthless, to get old". There are many idioms in the TLI Proverbs and Idioms Dictionary relating the word "eski (old)". Some of these idioms are "old pines have turned into glasses, closing old notebooks, old baths old bowls, taking on the old identity, bringing a new tradition to the old village, not looking for the old one, if the old were in vogue (or reputation) it would rain light on the flea market".

The concept of obsolescence has been tried to be defined by the organization and management employees. Burke (1969) studied skill obsolescence and, in his study with engineers, found that age was a factor in skill obsolescence. For example, Pazy (1994), who studied the cognitive scheme of professional obsolescence, interviewed 50 professionals and tried to understand the concept of obsolescence and found that professionals attribute different meanings to obsolescence. Pazy (1996), in his other study, also stated that there are three directions of research on obsolescence, the first of which is that the meaning of the concept of obsolescence differs; he stated that the other is about self-improvement and updating awareness, and another is about differences in career steps. Pazy (1996) sees the inability to adapt to change as an essential factor leading to obsolescence. Fossum et al. (1986) mentioned about skill obsolescence and discussed the concept of obsolescence in terms of human resources. Fossum et al. (1986) identified the factors affecting skill obsolescence as motivational, individual, organizational and extrinsic factors.

Shearer and Steger (1975) discussed workforce obsolescence and identified 12 factors leading to managerial and technical work obsolescence. They found that the factors that prevent obsolescence are the high need for success and participation in management. Besides, in their studies, managerial obsolescence, in contrast to professional obsolescence, was associated with more experience, but less with education. Warmington (1974) viewed obsolescence as a systems approach and explained it by taking into account the organization's business/factory, process and output. If these processes do not meet the conditions of the day, they are considered obsolete. Başaran (2008) defined organizational obsolescence as the gradual insufficiency of an employee who was sufficient when he started his work. He explained the personal reasons for obsolescence as a) being prone to obsolescence, b) emotional disturbance, c) unsuitable working habits, d) inappropriate management style.

Mohan et al. (2001) identified the factors that cause obsolescence and listed them as follows: It has been stated that obsolescence is due to its superior attitude, followed by organizational climate and organizational support. He inferred that superiors played an important role in the development of the administrators of the organization (Chauhan \& Chauhan 2005), and they also found that the organizational climate and the superiors' attitude contributed to managerial obsolescence. Murillo (2011) deals with the concept of obsolescence with its technical and economic obsolescence dimensions. It is atrophy in skills because of the physical weakening of the employee due to the technological age and illness of the employee and not using his skills sufficiently. These are the losses that result from the change of technology and the new skills required by the organization as a result of economic obsolescence, changing depending on the sector and the company, and being unable to keep up with these changes. Other studies take the age variable of the employee as a factor in obsolescence. Burke (1969) surveyed 50 engineers. It has been observed that elderly engineers react less and are not fully equipped to deal with the work. Similarly, in the studies of van Loo et al. (2001), older workers were seen as a high-risk 
group for skill obsolescence. Toner (2011) concluded that the quality and quantity of employee skills are crucial to innovation and economic performance.

Van Loo et al. (2001) investigated the relationship between risk factors and skill obsolescence and the role of measures. It was expected that risk factors would cause skill obsolescence and that the measures taken would prevent skill obsolescence. As expected, obsolescence is related to business conditions. Older workers were seen as a high-risk group for skill obsolescence. Improving the conditions in the workplace was seen as a preventive factor. It was stated that developments in technological, organizational and demographic changes also caused skill obsolescence. Contrary to the age of the employee, the age of the organization is a factor in aging and different results have been obtained in some studies. For example, according to Sorensen and Stuart (2000), an organization can innovate and prevent it from obsolescence with aging. For example, they can discover new developments in the field of biotechnology, increase the number of patents and continue as a leading company.

Searching the literature, we realize that the concept of managerial obsolescence has been studied for many years (see Başaran, 2008; Burke, 1969; Fossum et al., 1986; van Loo et al., 2001; Warmington, 1974), as the renewal of the concept of obsolescence (see Knight, 1998; Rothman \& Perrucci; 1971; Sorensen \& Stuart, 2000; Shaffer, 1969); change (see Chauhan \& Chauhan, 2004, 2008) lifelong learning, labor aging, knowledge obsolescence, human resources (see Fossum et al., 1986; Murillo, 2011; Pazy, 1996; Toner, 2011). It seems that both qualitative (see Pazy, 1994) and quantitative research (see, Shearer \&Steger, 1975; Rothman \& Perrucci, 1971) have been done in some fields except education. However, the fact that most of these studies are in business (see, Jones, Chanko, Roberts, 2004; Mohan, Chauhan \& Chauhan, 2001; Chauhan \& Chauhan, 2004, 2005; 2008; 2009) and technical fields (see. Sorensen \& Stuart, 2000) should be taken into consideration. Chauhan \& Chauhan (2009) say that it is necessary to combat obsolescence. As it is seen above, organizational and managerial obsolescence have been studied in different fields. Only two studies related to education were on pedagogical obsolescence (see, MacNeill \& Cavanagh, 2006) and IT related concept of obsolescence. MacNeill and Cavanagh (2006) criticized New Public Management (NPM) reform as the managerial reforms that accompanied accountability affected schools negatively. As a result of the NPM movement pedagocical obsolescence occured and restricted school principals' pedagogical leadership. Another topic related to obsolescence occurred at schools is planned obsolescence which is related to IT used at schools. Wandera (2015) also mentioned this threat, how schools respond to this and its effects on the teaching and learning process.

The fight against obsolescence should be at both an organizational and individual level. The problem of obsolescence should be shared between the two stakeholders: Individual and organization. Self-improvement and self-improvement initiatives can be done at an individual level. At the organizational level, employees can improve themselves through continuous training (Chauhan \& Chauhan, 2009). Up to now, antiquity has been studied in different sectors, but no tool has been developed to measure the level and dimensions of professional obsolescence in educational organizations. Therefore, this study aims to develop a scale that will determine the factors causing professional obsolescence in the field of education, to determine the dimensions that lead to obsolescence, and to determine the antiquity levels of these dimensions.

\section{METHOD}

\subsection{Working Group}

A total of 1001 school principals were reached within the scope of the research. Three people who did not respond to five consecutive items were excluded from the analysis. Of the 998 participants taking part in the analyses, $151(15 \%)$ were women and $847(85 \%)$ were men. In 
the Ministry of National Education system, school sizes are symbolized by the letters A, B and $\mathrm{C}$, depending on the number of students. Although it varies depending on the school level, $\mathrm{A}$ type schools are relatively large ones, B type schools are medium-size and C type schools are small ones (MEB Eğitim Kurumları, 2009). 654 (66\%) of these participants work in A-type schools, $196(20 \%)$ in B and 146 (15\%) in C-type schools, two people did not specify. Again, $452(45 \%)$ of the participants work as principals in primary school, $268(27 \%)$ in secondary school, $268(27 \%)$ in high school, $4(0.4 \%)$ in both primary and secondary schools, $6(0.6 \%)$ the person did not specify. Of the participants, $36(4 \%)$ hold associate degrees, $771(77 \%)$ bachelor's degree, while 153 (15\%) completed their postgraduate education, and 34 (4\%) stated the other option.

With regards to the seniority of the participants as managers, $3(0.3 \%)$ people did not respond. There are $211(21 \%)$ people with seniority of fewer than three years as a manager, $210(21 \%)$ people with seniority of 4-6 years, $375(38 \%)$ people with seniority of 7-18 years, $170(17 \%)$ people with seniority of 19-30 years, $29(3 \%)$ people with a seniority of 30 or more years.

The number of participants who stated that "they took a management course after 1998 and were appointed after the exam", that is to say, those who attended in-service seminars before becoming managers is 406 (41\%); those who stated that "they were appointed before 1998 and took management courses and seminars" is $165(17 \%)$. The number of participants who stated that "they did not take courses and seminars related to management" is $299(30 \%)$; and participants stating that "they took courses and seminars or graduated after becoming a manager" is $56(6 \%) .67(7 \%)$ people chose "the other" option.

The duration of participation of the participants in professional development activities in the last 18 months varies between 0 and 130 days with an average of 12 days. The number of days on which these activities are compulsory varies between 0 and 120, with an average of 8 days. Again, the effectiveness levels of these activities ranged from 1: not at all effective to 5: very effective and the average was 4 . While $798(80 \%)$ of those participating in these events stated that they did not pay at all, $134(13 \%)$ stated that they paid some and $66(7 \%)$ paid the whole price. Similarly, $729(73 \%)$ of $921(92 \%)$ people who stated that these activities took place during regular working hours said that the activities were organized in a way that they would allow them to participate. 76 out of $77(8 \%)$ people who stated that events were organized outside of regular working hours stated that they received additional payment to participate in these activities. The number of those who want to participate in more activities than the ones available in the last 18 months is $523(52 \%)$, and the number of those who do not is $474(47 \%)$, one person did not specify. The reasons stated by those who did not participate although they wished to participate are as follows.

Table 1. Reasons for participants not to attend in-service activities.

\begin{tabular}{lc}
\hline Reasons & Frequency \\
\hline I did not have the prerequisites for participation (e.g., qualifications, experience, & 60 \\
seniority). & 61 \\
Professional development activity was too expensive / I could not afford it. & 80 \\
I could not get the necessary support from my higher institution. & 223 \\
Activity hours coincided with my work schedule. & 105 \\
I did not have time because of my family responsibilities. & 249 \\
There was no professional development activity suitable for me. & 62 \\
\hline
\end{tabular}

As Table 1 shows, it is seen that the most frequently stated reasons are that the activity is not suitable for the participant, the activity time is not suitable for the participant, and they do not 
have time due to family responsibilities. The frequency of choosing the expressions that define the attitudes of the participants to support the professional development of their superiors is given in the table below.

Table 2. Participants' views on the attitudes of their superiors to support their professional development.

\begin{tabular}{lc}
\hline Views & Frequency \\
\hline He is insensitive to the education needs of its subordinates. If subordinates are sent for & \\
training, they do not offer a separate time slot for this training. & 214 \\
He thinks of his job only as applying corporate goals and policies. It does not take into \\
account the professional needs of subordinates.
\end{tabular}

As seen in Table 2, those who did not find the attitudes of their superior superiors supportive stated 216 opinions, while those who found supportive expressed 815 opinions.

\subsection{Data Collection Tool}

Professional Obsolescence Scale (POS) given in the appendix has been developed to determine the professional and organizational obsolescence levels of primary, secondary and high school principals. In this scale development process, the following steps were followed in line with the suggestions of Crocker and Algina (2006) and Cronbach (1984).

1. Defining the feature to be measured and writing the items

While developing the scale, the items of the scale in the article titled "Are you on the verge of antiquity?" published by Chauhan and Chauhan in 2009 and obtained permission for use were used. Also, the theoretical framework, which is included in Başaran's (2008) Organizational Behavior book and the following dimensions, was taken into consideration. In addition to these, items expressing information and communication technologies were written by the researchers and added to these items.

Başaran's (2008) definition of organizational obsolescence was taken into consideration and the four sub-dimensions determined there were taken as a basis. These dimensions are summarized below.

- Being suitable for obsolescence: Under this dimension, items were written about the decrease in the motivation of the employee for organizational goals, the negative attitude towards learning, the hardening of actions, especially in attitudes, the decrease in physical strength and aging.

- Emotional Disorder: Items were written for the employees having difficulty in the workplace and prolonged frustration, having feelings of inferiority and guilt, having a constant headache, being stuck with personal problems, taking alcohol continuously and getting vaccinated, smoking and using drugs. 
- Inappropriate Working Habit: Items expressing the incompatibility of the employee's working method that has turned into a habit in the workplace and the working style required by the organization and the task were written.

- The inappropriateness of the Management Style: Items were written that the management style of the organization was not suitable for the personality characteristics of the employee, the employee was forced to carry out a task beyond the competence of the employee, the objectives of the organization were uncertain, the superiors ignored the obsolescence, the counseling was insufficient and the employee was not assigned to a position where the employee would be effective.

Chauhan and Chauhan (2009) stated that there are two main factors in the scale of professional obsolescence that they developed, these are individual and organizational factors, and there are sub-factors under them. This scale consists of 34 items and measures obsolescence in 8 dimensions. Four of them are organizational factors (organizational climate, organizational support, superior attitude, on-the-job development activities) and four are individual factors. Individual factors are listed as professional knowledge and skills, development motivation, attitude towards learning, taking the initiative in self-development. These dimensions are briefly summarized below.

a. Organizational climate: Organizational climate encourages autonomy, innovation, and reward for high performance.

b. Organizational support: The organization develops and supports the training and career plan for its employees.

c. The attitude of superiors: Provides support for the development of subordinates.

d. On-the-job development activities: Employees perceive on-the-job activities that are suitable for improving/updating themselves as appropriate activities for self-improvement.

e. Professional knowledge and skills: Employees perceive that their knowledge and skills are appropriate for their job.

f. Development/update motivation: employees are motivated to improve themselves.

g. Attitude towards learning: Positive or negative attitude towards learning.

$\mathrm{h}$. Taking the initiative in self-development: Employees take the initiative in self-improvement.

Sixty-three items were written first on the scale. Although all of the items are scored between 1 and 5, the attributes indicated by the numbers differ. For example; Some items are scored between 1: Not at all effective and 5: Very effective, while some items are scored between 1: Not at all important and 5: Very important. No item requires reverse coding. In addition, low scores from each of the first three sub-dimensions of the scale and high scores from the fourth sub-dimension indicate that the professional obsolescence is high.

2. Expert opinion and revisions of the items

The draft form was prepared by adding demographic information together with the prepared items, and it was examined by five experts in the field and two measurement and evaluation experts. The appropriateness, scoring, and correction suggestions, if any, of each item were requested from the experts. There was no change in the number of items in line with the recommendations. The draft form was finalized by making textual corrections.

\section{Pre-plot}

The draft form prepared at this stage was applied to 10 school principals in terms of clarity, understandability and determination of the implementation period. Five items were corrected textually in line with the verbal feedback received at the end of the application. 


\section{Application and determination of psychometric properties}

The application was carried out both with paper-pencil and using Google Forms. To determine the psychometric properties of the measurements obtained, validity and reliability evidence was presented.

\subsection{Data Analysis}

First of all, the data set was examined and found out that no variable has more than $10 \%$ missing values. But based on all cells, the proportion of missing data was found to be $0.1 \%$. The assignment was made with EM (Expectation - Maximization) algorithm for the missing data. Seven people marking all items as five were excluded from the analysis.

For the evidence of the construct validity of the scale, the responses of 991 individuals were first performed with 63 items and Principal Axis Analysis (PA) using the varimax orthogonal rotation method using the polychoric correlation matrix. In PA, the minimum factor loading was .50 (Todman \& Dugard, 2007), and for the detection of overlapping items, the difference between the factor loading of the same item on two factors was taken as .10 (Büyüköztürk, 2019). In addition, the "Checklist for Reporting EFA" proposed by Akbaş et al. (2019) was used for reporting. Although the responses to the items are graded between 1 and 5, the qualifiers for the grades differ. For example; Some items are scored between 1: Not at all effective and 5: Very effective, while some items are scored between 1: Not at all important and 5: Very important. For this reason, Item Response Theory, which examines the validity and reliability evidence at an item level, was taken as a basis.

IRT is a measurement theory that models the relationship between individuals' response patterns to items and their abilities. The property measured in the Classical Test Theory is the sum of the responses given by individuals to the items of a test. Therefore, this observed score is the sum of the person's true score and measurement errors (Crocker \& Algina, 2006). For this reason, test and item statistics cannot be calculated independently from the group or the items. In IRT, on the other hand, item parameters can be estimated independently from the sample and ability parameters from the items. This feature is called parameter invariance (DeMars, 2010).

Models used for items scored in two and multi-categories in IRT differ. While Rasch, 1PL, 2PL and 3PL models are used for dichotomously scored items, Partial Credit Model (adjacent category approach) is used as an extension of 1PL model, and Graded Response Model (cumulative category approach) is used as an extension of 2PL model for polytomous scored items (Tang, 1996; Yürekli, 2010). In this study, since the categories are scored cumulatively, the item and test parameter estimates were examined with Samejima's Graded Response Model. IRT assumptions dimensionality, local independence and model-data fit were tested, and parameter invariances were examined. PA for dimensionality, C2 statistics for model-data fit were examined; for parameter invariance, item and study group were randomly divided into two and correlation values were examined (DeMars, 2010). in addition to item discrimination and threshold parameters, item and test information functions, marginal and empirical reliability coefficients. Also, the Stratified Alpha coefficient recommended by Cronbach et al. (1965) to be used in multidimensional scales was also examined. Because even in scales where unidimensionality assumption is not provided, Cronbach's Alpha coefficient can give very high values (Tan, 2009).

\section{FINDINGS}

The KMO (Kaiser Mayer Olkin) value calculated using the polychoric correlation matrix to examine the suitability of the data for factor analysis was found to be 0.94 and the Bartlett sphericity test was found to be significant $\left(\chi^{2}=34742.74 ; \mathrm{sd}=1081 ; p<0.05\right)$. In the first stage 
of the Principal Axis Analysis, which was carried out with 63 items, it was seen that there were eight dimensions with eigenvalues greater than one. The scree plots obtained as a result of PA and parallel analysis are given below.

Figure 1. Scree plots obtained as a result of $P A$ and parallel analysis.

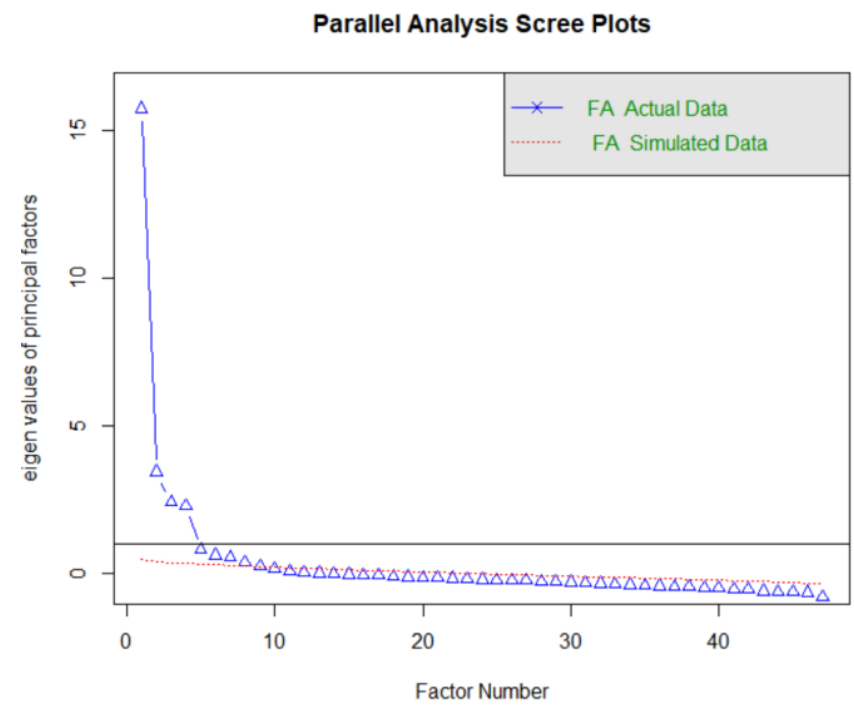

When Figure 1 was examined, it was seen that the structure was four-dimensional according to the results of PA and parallel analysis. As a result of Varimax rotation items with a factor loading of less than $0.50(7,8,9,10,14,15,17,18,32,33,34,46,51)$ and overlapping items $(13,16,45)$ were removed from the scale. PA results for this structure are given in the table below.

Table 3. PA Varimax rotation results in Professional Obsolescence Scale factor loadings, eigenvalues, explained variance proportions.

\begin{tabular}{lcccc}
\hline Items & $\begin{array}{c}\text { F1: Being Open } \\
\text { to Professional } \\
\text { Development }\end{array}$ & $\begin{array}{c}\text { F2: Job-Ability } \\
\text { Harmony in } \\
\text { Profession }\end{array}$ & $\begin{array}{c}\text { F3:Organizational } \\
\text { Support in } \\
\text { Professional } \\
\text { Development }\end{array}$ & $\begin{array}{c}\text { F4: Professional } \\
\text { Burnout }\end{array}$ \\
\hline M54 & $\mathbf{0 . 8 5 0}$ & 0.080 & 0.090 & -0.020 \\
M55 & $\mathbf{0 . 8 2 0}$ & 0.120 & 0.080 & 0.020 \\
M58 & $\mathbf{0 . 8 1 0}$ & 0.200 & 0.080 & 0.060 \\
M63 & $\mathbf{0 . 8 1 0}$ & 0.170 & 0.130 & 0.080 \\
M53 & $\mathbf{0 . 7 8 0}$ & 0.080 & 0.230 & -0.050 \\
M57 & $\mathbf{0 . 7 7 0}$ & 0.150 & 0.160 & 0.050 \\
M59 & $\mathbf{0 . 7 7 0}$ & 0.180 & 0.140 & 0.100 \\
M61 & $\mathbf{0 . 7 6 0}$ & 0.250 & 0.030 & 0.070 \\
M62 & $\mathbf{0 . 7 4 0}$ & 0.160 & 0.170 & 0.160 \\
M56 & $\mathbf{0 . 7 3 0}$ & 0.090 & 0.140 & 0.060 \\
M60 & $\mathbf{0 . 7 0 0}$ & 0.140 & 0.210 & 0.010 \\
M50 & $\mathbf{0 . 7 0 0}$ & 0.210 & 0.050 & 0.110 \\
M52 & $\mathbf{0 . 6 8 0}$ & 0.060 & 0.290 & 0.020 \\
M48 & $\mathbf{0 . 6 8 0}$ & 0.260 & 0.120 & 0.000 \\
M49 & $\mathbf{0 . 6 6 0}$ & 0.070 & 0.210 & 0.090 \\
M26 & $\mathbf{0 . 6 4 0}$ & 0.100 & 0.170 & 0.010 \\
M47 & $\mathbf{0 . 6 2 0}$ & 0.120 & 0.270 & 0.140
\end{tabular}




\begin{tabular}{lcccc}
\hline & & & & \\
M24 & $\mathbf{0 . 6 1 0}$ & 0.100 & 0.040 & 0.150 \\
M25 & $\mathbf{0 . 6 1 0}$ & 0.230 & 0.150 & 0.010 \\
M39 & $\mathbf{0 . 5 9 0}$ & 0.290 & 0.080 & 0.160 \\
M27 & $\mathbf{0 . 5 8 0}$ & 0.200 & 0.230 & -0.010 \\
M40 & $\mathbf{0 . 5 4 0}$ & 0.190 & 0.130 & 0.130 \\
M38 & $\mathbf{0 . 5 4 0}$ & 0.220 & -0.010 & 0.060 \\
\hline M4 & 0.190 & $\mathbf{0 . 8 1 0}$ & 0.080 & 0.050 \\
M2 & 0.190 & $\mathbf{0 . 8 0 0}$ & 0.060 & 0.000 \\
M3 & 0.190 & $\mathbf{0 . 8 0 0}$ & 0.180 & -0.050 \\
M1 & 0.170 & $\mathbf{0 . 8 0 0}$ & 0.080 & -0.060 \\
M6 & 0.350 & $\mathbf{0 . 6 2 0}$ & 0.140 & -0.110 \\
M11 & 0.400 & $\mathbf{0 . 6 1 0}$ & 0.010 & -0.010 \\
M5 & 0.240 & $\mathbf{0 . 5 7 0}$ & 0.280 & -0.040 \\
M12 & 0.320 & $\mathbf{0 . 4 6 0}$ & 0.230 & -0.060 \\
\hline M29 & 0.260 & 0.140 & $\mathbf{0 . 7 8 0}$ & -0.010 \\
M30 & 0.150 & 0.120 & $\mathbf{0 . 7 8 0}$ & 0.010 \\
M31 & 0.040 & 0.000 & $\mathbf{0 . 7 2 0}$ & 0.010 \\
M28 & 0.280 & 0.200 & $\mathbf{0 . 7 1 0}$ & -0.080 \\
M36 & 0.130 & 0.060 & $\mathbf{0 . 6 7 0}$ & -0.020 \\
M35 & 0.290 & 0.190 & $\mathbf{0 . 6 5 0}$ & -0.020 \\
M37 & 0.360 & 0.130 & $\mathbf{0 . 5 5 0}$ & 0.120 \\
\hline M22 & -0.010 & -0.100 & -0.090 & $\mathbf{0 . 7 0 0}$ \\
M21 & 0.000 & 0.000 & -0.050 & $\mathbf{0 . 6 9 0}$ \\
M43 & 0.190 & 0.130 & 0.090 & $\mathbf{0 . 6 4 0}$ \\
M19 & -0.140 & -0.160 & -0.060 & $\mathbf{0 . 6 1 0}$ \\
M42 & 0.170 & 0.080 & 0.150 & $\mathbf{0 . 6 0 0}$ \\
M23 & 0.010 & -0.080 & -0.010 & $\mathbf{0 . 5 7 0}$ \\
M20 & 0.000 & -0.110 & 0.030 & $\mathbf{0 . 5 6 0}$ \\
M41 & 0.230 & 0.120 & 0.040 & $\mathbf{0 . 5 5 0}$ \\
M44 & 0.200 & 0.040 & -0.060 & $\mathbf{0 . 4 9 0}$ \\
\hline Eigenvalues* & 4.77 & 4.25 & 0.807 \\
Explained Variance & 12.53 & $10 \%$ & $9 \%$ & 0.858 \\
\hline Cronbach's Alpha & $27 \%$ & 0.872 & & \\
\hline Stratified Alpha & 0.945 & & & \\
\hline * Four dimensions $w e$ & & \\
& 0.940 & rified & & \\
\hline
\end{tabular}

* Four dimensions were verified as a result of the parallel analysis.

As seen in Table 3, the 47 items got arranged in a four-dimensional structure explaining 53\% of the total variance. The items in each dimension were examined and the first dimension consisting of 23 items was named as "Being Open to Professional Development", the second dimension consisting of eight items was named as "Job-Ability Harmony in Profession", the third dimension consisting of seven items was named as "Organizational Support in Professional Development" and the fourth dimension of nine items was named as "Professional Burnout". When the internal consistency of each dimension was examined, it was seen that the Cronbach Alpha coefficients were over 0.81 and the Stratified Alpha coefficient of the fourdimensional structure was 0.94 . Therefore, it can be said that the scores have high reliability, according to Classical Test Theory (CTT). Definitions and sample items for each dimension are given below. 
Table 4. Description of dimensions and sample items.

\begin{tabular}{|c|c|c|}
\hline Dimensions & Desc & Sample items \\
\hline $\begin{array}{l}\text { F1: Being } \\
\text { Open to } \\
\text { Professional } \\
\text { Development }\end{array}$ & $\begin{array}{l}\text { School administrators' institutions for } \\
\text { their professional development should } \\
\text { be open to participating in internal or } \\
\text { external activities determined by their } \\
\text { superiors or themselves for their } \\
\text { professional development, and they } \\
\text { plan for these activities. }\end{array}$ & $\begin{array}{l}\text { M54: Your participation in a working group for } \\
\text { professional development } \\
\text { Very effective ... Not effective at all }\end{array}$ \\
\hline $\begin{array}{l}\text { F2: Job- } \\
\text { Ability } \\
\text { Harmony in } \\
\text { Profession }\end{array}$ & $\begin{array}{l}\text { It expresses to what extent school } \\
\text { administrators are aware of their } \\
\text { learning abilities and how they use } \\
\text { these skills in their professional } \\
\text { development. Also, it indicates the } \\
\text { compatibility of the knowledge, skills } \\
\text { and abilities of school administrators } \\
\text { with their job. }\end{array}$ & $\begin{array}{l}\text { M1: How appropriate is your current professional } \\
\text { knowledge for the job you are doing? } \\
\text { Very suitable... Not suitable } \\
\text { M4: How do you compare the skills you have with } \\
\text { the requirements of your job? } \\
\text { Above what the job requires ... Below what the job } \\
\text { requires }\end{array}$ \\
\hline $\begin{array}{l}\text { F3: } \\
\text { Organizational } \\
\text { Support in } \\
\text { Professional } \\
\text { Development }\end{array}$ & $\begin{array}{l}\text { It expresses to what extent school } \\
\text { administrators' superiors or institutions } \\
\text { support their professional } \\
\text { development, and to what extent they } \\
\text { encourage administrators' high } \\
\text { performance and innovative status. }\end{array}$ & $\begin{array}{l}\text { M30: To what extent does your institution make } \\
\text { long-term career planning of its managerial } \\
\text { personnel? } \\
\text { Very much ... Not at all } \\
\text { M29: To what extent do the policies at your } \\
\text { institution encourage you to study at a more } \\
\text { advanced level? } \\
\text { Very much ... Not at all }\end{array}$ \\
\hline $\begin{array}{l}\text { F4: } \\
\text { Professional } \\
\text { Burnout }\end{array}$ & $\begin{array}{l}\text { It refers to the personal, managerial and } \\
\text { organizational factors that will cause } \\
\text { the professional burnout of school } \\
\text { administrators. }\end{array}$ & $\begin{array}{l}\text { M21: How does the incompatibility of your } \\
\text { working style with your organization's working } \\
\text { style affect your job performance? } \\
\text { Very much ... Not at all } \\
\text { M22: To what extent does your organization's } \\
\text { management style conflict with your personality } \\
\text { affect your job performance? } \\
\text { Very much ... Not at all }\end{array}$ \\
\hline
\end{tabular}

The names given to the dimensions in Table 4 are based on the definitions and these definitions are made to cover all the items in the relevant dimension. Pearson's correlation coefficients between dimensions calculated based on raw scores are given below.

Table 5. Correlations between dimensions.

\begin{tabular}{lcccc}
\hline & F1 & F2 & F3 & F4 \\
\hline F1 & 1.000 & & & \\
F2 & $0.491^{*}$ & 1.000 & & \\
F3 & $0.410^{*}$ & $0.335^{*}$ & 1.000 & \\
F4 & $0.112^{*}$ & -0.047 & -0.003 & 1.000 \\
\hline
\end{tabular}

${ }^{*} p<0.05$.

When Table 5 is examined, it is seen that the Pearson correlation coefficients between the first three dimensions are greater than 0.30. Relationships between these dimensions are medium and positive. As the scores from one of these dimensions increase, the scores from the others 
also increase. The relationship between the fourth dimension and the first dimension is significant and at a low level (Field, 2009). In that case, a single score cannot be obtained from the whole scale; each dimension will be evaluated within itself.

Before examining item and test parameters according to the Samejima's Graded Response Model based on IRT, dimensionality, local independence, model-data fit assumptions should be tested. Eigenvalues and ratios for dimensionality, variance proportion explained by a single factor, and C2 statistics for model-data fit were examined. Findings regarding these tests are given in the table below.

Table 6. Statistics on assumptions for parameter estimates.

\begin{tabular}{lcccccccc}
\hline & $\begin{array}{c}\text { First } \\
\text { eigenvalue }\end{array}$ & $\begin{array}{c}\text { Second } \\
\text { eigenvalue }\end{array}$ & $\begin{array}{c}\text { Proportion of } \\
\text { eigenvalues }\end{array}$ & $\begin{array}{c}\text { Variances explained } \\
\text { by the single factor } \\
(\%)\end{array}$ & C2 & df & $p$ \\
\hline F1 & 12.919 & 1.295 & 9.97 & 56 & 2499.568 & 230 & 0.000 \\
F2 & 4.944 & 0.910 & 5.43 & 61 & 348.682 & 20 & 0.000 \\
F3 & 4.324 & 0.738 & 5.86 & 61 & 284.131 & 14 & 0.000 \\
F4 & 4.016 & 1.505 & 2.67 & 44 & 1105.835 & 27 & 0.000 \\
\hline
\end{tabular}

When Table 6 is examined, it is seen that the proportion of the first and second eigenvalues are more than 2.5 and the explained variances are greater than $30 \%$. Therefore, each dimension is one-dimensional in itself (Çokluk et al., 2014). Parallel analysis results support this finding. The size number of the test equals the number of latent features that can be locally independent. On the other hand, local independence is the condition in which the score to be obtained from an item by individuals with the same ability level is not affected by other items (Embretson and Reise, 2000). Therefore, it can be said that since the unidimensionality assumption is met, the local independence assumption is also met (Crocker and Algina, 2006; Hambleton and Swaminathan, 1985). According to the results of the C2 statistics, it was also observed that the model-data fit was achieved according to Samejima's Graded Response Model $(p<0.05)$. Parameters related to the items are given in the table below. Discrimination (a) parameters are classified as very high when it is 1.70 and above, according to Baker (2001). Although threshold parameters (b) are scaled between -3 and +3 in practice, theoretically, they take values between $-\infty$ and $+\infty$. As the $b$ value increases, the probability of an individual to mark the item in one of the higher categories increases with a $50 \%$ probability.

Table 7. Discrimination and threshold parameters for the Graded Response Model.

\begin{tabular}{ccccccc}
\hline \multirow{2}{*}{ Dimensions } & Items & \multicolumn{5}{c}{ Item parameters } \\
\cline { 2 - 6 } & F1 & $\mathrm{a}$ & $\mathrm{b} 1$ & $\mathrm{~b} 2$ & $\mathrm{~b} 3$ & $\mathrm{~b} 4$ \\
\hline & M54 & 3.439 & -2.889 & -2.223 & -1.066 & 0.111 \\
& M55 & 3.195 & -3.057 & -2.306 & -1.089 & 0.118 \\
& M63 & 3.285 & -3.229 & -2.481 & -1.284 & -0.053 \\
& M53 & 2.690 & -2.599 & -2.025 & -0.984 & 0.238 \\
& M57 & 2.654 & -2.655 & -2.036 & -0.901 & 0.326 \\
& M59 & 2.863 & -2.838 & -2.375 & -1.223 & 0.054 \\
& M62 & 2.491 & -3.222 & -2.461 & -1.157 & 0.167 \\
& M56 & 2.247 & -2.491 & -1.966 & -0.901 & 0.161 \\
& M50 & 2.056 & -3.286 & -2.231 & -0.929 & 0.501 \\
& M58 & 3.331 & -3.046 & -2.785 & -1.199 & 0.009 \\
& M60 & 2.194 & -3.687 & -2.904 & -1.468 & -0.098 \\
& M61 & 2.680 & -3.654 & -2.988 & -1.497 & -0.135 \\
& M48 & 1.930 & -2.924 & -2.070 & -0.855 & 0.585 \\
& M52 & 2.110 & -3.785 & -3.039 & -1.565 & -0.063
\end{tabular}




\begin{tabular}{|c|c|c|c|c|c|c|}
\hline & M26 & 1.667 & -2.941 & -2.099 & -0.973 & 0.256 \\
\hline & M47 & 1.737 & -3.356 & -2.493 & -1.080 & 0.613 \\
\hline & M25 & 1.646 & -4.003 & -2.976 & -1.519 & -0.103 \\
\hline & M24 & 1.443 & -3.705 & -2.949 & -1.663 & -0.157 \\
\hline & M39 & 1.538 & -4.527 & -3.579 & -1.819 & -0.128 \\
\hline & M38 & 1.303 & -3.225 & -2.861 & -1.733 & -0.310 \\
\hline & M27 & 1.560 & -2.839 & -2.329 & -1.262 & 0.273 \\
\hline & M40 & 1.261 & -3.730 & -3.442 & -2.339 & -0.803 \\
\hline & mean & 2.225 & -3.247 & -2.554 & -1.274 & 0.091 \\
\hline \multirow[t]{9}{*}{ F2 } & M4 & 3.102 & -3.217 & -2.541 & -1.380 & 0.332 \\
\hline & M2 & 3.027 & -3.112 & -2.498 & -1.236 & 0.453 \\
\hline & M3 & 2.869 & -3.278 & -2.627 & -1.444 & 0.025 \\
\hline & M1 & 2.986 & -3.121 & -2.511 & -1.618 & -0.032 \\
\hline & M6 & 1.730 & -3.785 & -2.864 & -1.616 & -0.023 \\
\hline & M11 & 1.790 & -4.642 & -3.897 & -2.039 & 0.043 \\
\hline & M5 & 1.524 & -4.194 & -2.661 & -1.397 & 0.427 \\
\hline & M12 & 1.239 & -5.119 & -3.718 & -1.617 & 0.441 \\
\hline & mean & 2.283 & -3.809 & -2.915 & -1.543 & 0.208 \\
\hline \multirow[t]{8}{*}{ F3 } & M29 & 3.585 & -1.861 & -1.177 & -0.221 & 0.957 \\
\hline & M30 & 2.629 & -1.672 & -0.932 & 0.153 & 1.317 \\
\hline & M28 & 2.771 & -2.081 & -1.321 & -0.345 & 0.848 \\
\hline & M31 & 1.582 & -1.381 & -0.485 & 0.476 & 1.858 \\
\hline & M36 & 1.513 & -1.062 & -0.699 & 0.017 & 0.824 \\
\hline & M35 & 1.874 & -2.458 & -1.655 & -0.650 & 0.821 \\
\hline & M37 & 1.522 & -3.234 & -2.068 & -0.585 & 1.098 \\
\hline & mean & 2.211 & -1.964 & -1.191 & -0.165 & 1.103 \\
\hline \multirow[t]{10}{*}{$\mathrm{F} 4$} & M22 & 2.343 & -1.687 & -0.878 & 0.006 & 0.992 \\
\hline & M21 & 2.304 & -1.829 & -0.940 & -0.082 & 0.916 \\
\hline & M43 & 1.351 & -2.836 & -1.675 & -0.218 & 1.338 \\
\hline & M42 & 1.215 & -2.683 & -1.615 & -0.089 & 1.459 \\
\hline & M19 & 1.319 & -1.848 & -0.456 & 0.705 & 2.027 \\
\hline & M23 & 1.382 & -2.267 & -1.065 & 0.178 & 1.627 \\
\hline & M20 & 1.329 & -1.642 & -0.705 & 0.260 & 1.456 \\
\hline & M41 & 1.108 & -3.601 & -2.239 & -0.641 & 1.115 \\
\hline & M44 & 0.894 & -2.489 & -1.927 & -0.752 & 0.314 \\
\hline & mean & 1.472 & -2.320 & -1.278 & -0.070 & 1.249 \\
\hline
\end{tabular}

When Table 7 is examined, it is seen that in the first dimension, item discrimination, in other words, the information given by the items about the structure varies between 1.261 (M40) and 3.439 (M54), and the average discrimination is 2.225 . When the threshold parameters are examined, with a $50 \%$ probability, the average ability level required for individuals to mark categories higher than 1 instead of 1 is -3.247 ; the average ability level required for individuals to mark categories higher than 2 instead of 2 is -2.554 ; the average ability level required for individuals to mark categories higher than 3 instead of 3 is -1.274 ; the average ability level required for individuals to mark categories for 5 instead of 4 is 0.091 . The marginal reliability coefficient for this dimension is 0.937 ; the empirical reliability coefficient is 0.938 .

In the second dimension, it is seen that the information given by the items varies between 1.239 (M12) and 3,102 (M4), and the average discrimination is 2.283. When the threshold parameters are examined, with a 50\% probability, the average ability level required for individuals to mark categories higher than 1 instead of 1 is -3.809 ; the average ability level required to mark categories higher than 2 instead of 2 is -2.915 ; the average ability level required to mark categories higher than 3 instead of 3 is -1.543 ; the average ability level required for individuals to mark categories for 5 instead of 4 is 0.208 . The marginal reliability coefficient for this dimension is 0.857 ; the empirical reliability coefficient is 0.867 . 
In the third dimension, it is seen that the information given by the items varies between 1.513 (M36) and 3.585 (M29), and the average discrimination is 2.221. When the threshold parameters are examined, with a 50\% probability, the average ability level required for individuals to mark categories higher than 1 instead of 1 is -1.964 ; the average ability level required for marking categories higher than 2 instead of $2-1.191$; the average ability level required to mark categories higher than 3 instead of 3 is -0.165 ; the average ability level required for individuals to mark categories for 5 instead of 4 is 1.103 . The marginal reliability coefficient for this dimension is 0.893 ; the empirical reliability coefficient is 0.894 .

In the fourth dimension, it is seen that the information given by the items varies between 0.894 (M44) and 2.343 (M22), and the average discrimination is 1.472. When the threshold parameters are examined, with a 50\% probability, the average ability level required for people to mark categories higher than 1 instead of 1 is -2.320 ; the average ability level required to mark categories higher than 2 instead of 2 is -1.278 ; the average ability level required to mark categories higher than 3 instead of 3 is -0.070 ; the average ability level required for individuals to mark categories for 5 markings instead of 4 is 1.249 . The marginal reliability coefficient for this dimension is 0.850 ; the empirical reliability coefficient is 0.854 .

Test information function and standard errors for these dimensions are given below. When Figure 2 is examined, it can be said that the structures measured in the first and second dimensions measure individuals in the $-\infty$ to -1 ability range, and the structures measured with the third and fourth dimensions measure the individuals in the -2 to +2 ability range with relatively little error. As we move away from these ability ranges, it is seen that the standard errors of measurement increase.

Apart from this information, one of the superior features of IRT is parameter invariance. In other words, it is the estimation of item parameters independent from the sample, and ability parameters (theta- $\theta$ ) independently from item parameters. Providing parameter invariance is, therefore, a proof of validity (DeMars, 2010; Baker, 2016). For this purpose, the rows in the data set were divided into two groups as odd and even, and the correlation between item parameters obtained from these groups was calculated. Besides, the columns belonging to the items in the data set were divided into two groups as odd and even, and the correlation between the ability (theta) parameters obtained from these groups was calculated. Correlation coefficients for item and ability parameter invariance are given in Table 8 below.

Table 8. Correlation coefficients for item and ability parameter invariance.

\begin{tabular}{lccc}
\hline Dimensions & $\mathrm{a}$ & mean $\mathrm{b}$ & theta \\
\hline F1 & 0.950 & 0.929 & 0.904 \\
F2 & 0.948 & 0.978 & 0.781 \\
F3 & 0.949 & 0.986 & 0.752 \\
F4 & 0.833 & 0.989 & 0.608 \\
\hline
\end{tabular}


Int. J. Assess. Tools Educ., Vol. 8, No. 2, (2021) pp. 257-278

Figure 2. Test information functions and standard errors regarding dimensions.

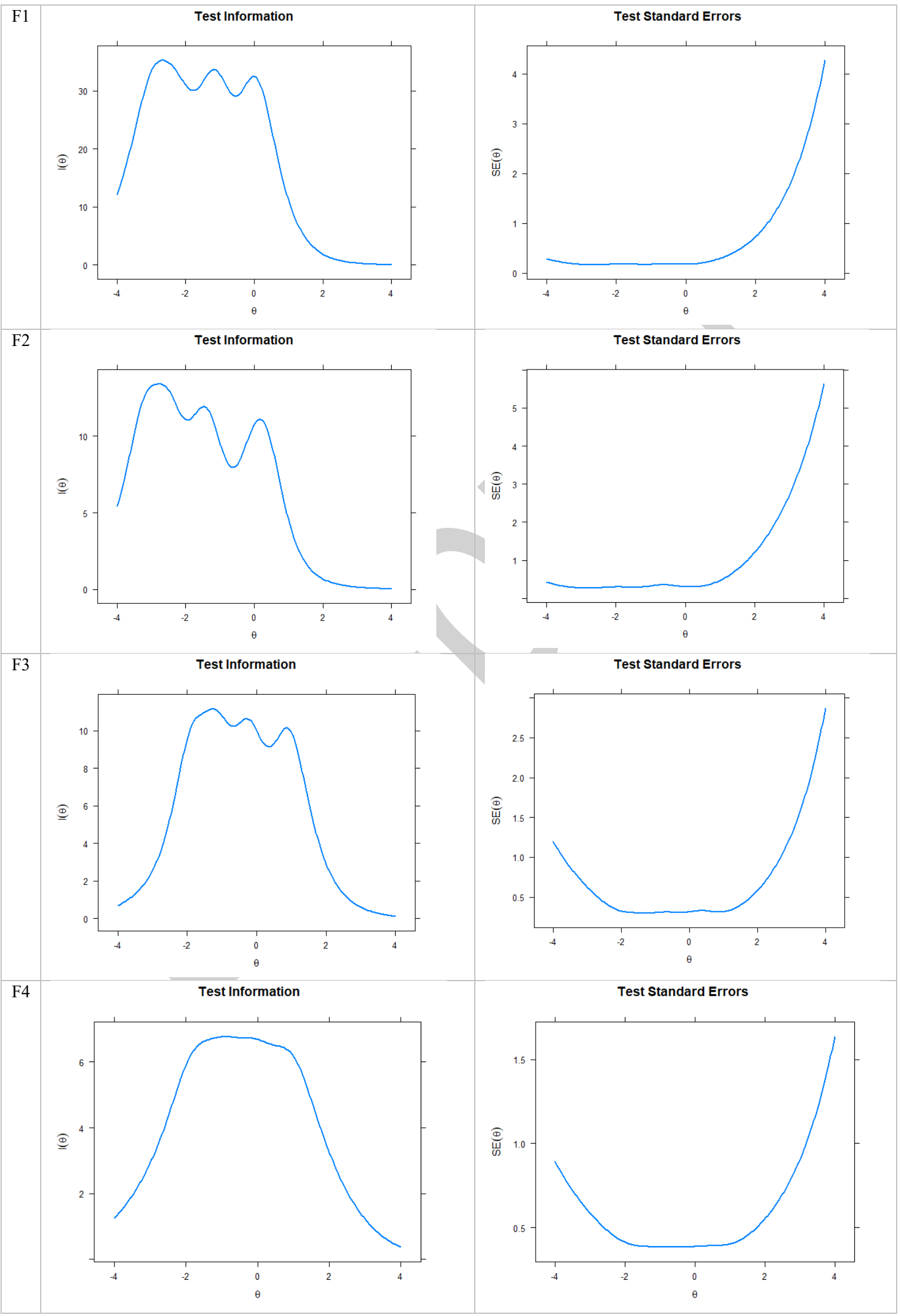


When the table is examined, it is seen that all correlation coefficients have medium and high correlation above 0.60. This finding indicates that item parameters can be estimated independently from the group and ability parameters can be predicted independently from the items. Finally, the number of materials, the lowest and highest scores and average values of the four-dimensional structure reached in Table 9 are given.

Table 9. Descriptive statistics on POS sub-dimensions.

\begin{tabular}{lccccc}
\hline Dimensions & $\begin{array}{c}\text { Item } \\
\text { numbers }\end{array}$ & Min. & Max. & Mean & $\begin{array}{c}\text { Mean } \\
\text { (Five point } \\
\text { likert scale) }\end{array}$ \\
\hline F1: Being Open to Professional Development & 23 & 23 & 115 & 97.442 & 4.237 \\
\hline F2: Job-Ability Harmony in Profession & 8 & 8 & 40 & 34.308 & 4.288 \\
\hline $\begin{array}{l}\text { F3: Organizational Support in Professional } \\
\text { Development }\end{array}$ & 7 & 7 & 35 & 24.231 & 3.461 \\
\hline F4: Professional Burnout & 9 & 9 & 45 & 30.806 & 3.423 \\
\hline
\end{tabular}

When Table 9 is examined, it is seen that the average scores obtained from each dimension vary between 3.423 and 4.288 out of five. The averages of the third and fourth dimensions are relatively lower than the first two dimensions. In that case, it can be stated that managers perceive more professional obsolescence in "Organizational Support in Professional Development" and "Professional Burnout".

\section{DISCUSSION and CONCLUSION}

This research aimed to develop a scale that will determine the factors leading to professional obsolescence in the field of education. As a result of the analyses made in this context, a fourdimensional scale consisting of 47 items was developed to show the professional antiquity of school administrators. The dimensions of the scale items that will determine the professional obsolescence of school administrators were found as "Being Open to Professional Development", "Job-Ability Harmony in Profession", "Organizational Support in Professional Development", "Professional Burnout". A total score is not obtained from these dimensions, and each dimension is evaluated descriptively in itself. Low scores in the first three dimensions and high scores in the last dimension show that professional obsolescence is high. In other words, not being open to professional development, lack of or low adaptation to work skills in the profession, lack of or low organizational support in professional development, high Professional Burnout indicate professional obsolescence. It is seen that the items in "Professional Burnout", one of the dimensions that emerged in this study, are the personal factors in organizational obsolescence stated by Başaran (2008), in a single group. Again, one of the dimensions in this scale, "Organizational Support in Professional Development" was also proposed as a dimension in the scale developed by Chauhan and Chauhan (2009), and a similar grouping was observed here. Another dimension that emerged in this study is the dimension of "Job -Ability Harmony in Profession", again Chauhan and Chauhan (2009) show similarities with the dimension of "professional knowledge and skills", which is a factor in professional obsolescence. The dimension of "Being Open to Professional Development" comprises a combination of several dimensions related to professional development in the scale developed by Chauhan \& Chauhan (2009).

Professional development activities are an important factor that prevents knowledge and ability obsolescence. The averages of the dimensions show that school administrators are quite good in the dimension of "Being Open to Professional Development" and it is consistent with the findings of participating in professional development activities above. In the dimension of "Job- 
Ability Harmony in Profession", again, it can be said that managers find their knowledge and ability suitable for their job. However, it can be said that "Organizational Support in Professional Development" is not perceived very high among these dimensions. The fact that the "Professional Burnout" is above average may indicate that school administrators are prone to professional obsolescence.

As a result, this four-dimensional scale developed to measure the professional antiquity of school administrators can be used both to determine whether school administrators are open to professional development and to determine the level of competence of their knowledge and ability while performing their profession. Also, the scale developed can be used both to determine the organizational support of school administrators in professional development and to determine the factors that will cause them to become obsolete. Moreover, the variables (age, education level, innovation, change, etc.) that are stated in the professional obsolescence scale developed and other variables that are related to professional obsolescence can be studied.

\section{Declaration of Conflicting Interests and Ethics}

The authors declare no conflict of interest. This research study complies with research publishing ethics. The scientific and legal responsibility for manuscripts published in IJATE belongs to the author(s). Ethics Committee Number: Başkent University/Faculty of Education, 17162298.600-291.

\section{Authorship Contribution Statement}

Sadegül Akbaba Altun: Investigation, Resources, Introduction, Methodology, Findings, Discussion, Supervision, and Validation. Şener Büyüköztürk: Investigation, Resources, Methodology, Supervision, and Validation. Merve Yıldırım Seheryeli: Method, Software, Analysis, Findings.

\section{ORCID}

Sadegül Akbaba Altun (iD https://orcid.org/0000-0001-5690-6088

Şener Büyüköztürk (i) https://orcid.org/0000-0002-0898-1697

Merve Y1ldırım Seheryeli id https://orcid.org/0000-0002-1106-5358

\section{REFERENCES}

Akbaş, U., Karabay, E., Yıldırım-Seheryeli, M., Ayaz, A., \& Demir, Ö. O. (2019). Comparison of Exploratory Factor Analysis Studies in Turkish Measurement Tools Index According to Parallel Analysis Results. Journal of Theoretical Educational Science, 12(3), 1095 1123. https://doi.org/10.30831/akukeg.453786

Baker, F. B. (2016). Madde Tepki Kuraminın Temelleri [Fundamentals of Item Response Theory]. (N. Güler, Ed., \& M. İlhan, Çev.) Pegem Akademi.

Başaran, İ.E. (2008). Örgütsel Davranış [Organizational Behavior]. Ekinoks Yayınları.

Burke, R.J. (1969). Effects of aging on engineer's satisfactions and mental health: Skill obsolescence, Academy of Management Journal, 12(4), 479-486. https://doi.org/10.546 $\underline{5 / 254736}$

Büyüköztürk, Ş. (2019). Sosyal Bilimler Iç̧in Veri Analizi El Kitabı [Manual of Data Analysis for Social Sciences] (26. bask1). Pegem Akademi.

Chauhan, S.P., \& Chauhan, D. (2004). Professional Obsolescence: Causes and Preventive Measures. Indian Journal of Industrial Relations, 39(3), 347-363. http://www.jstor.org/s table/27767911

Chauhan, S.P., \& Chauhan, D. (2005). Overcoming Managerial Obsolescence: The key to human development. Pritam Singh, Ajay Singh, and Daisy Chauhan, (Eds.), in Creating Value Through People (pp. 321-38). Excel Books. 
Chauhan, S.P., \& Chauhan, D. (2008). Human Obsolescence: A Wake-up Call to Avert a Crisis. Global Business Review, 9(1), 85-100. https://doi.org/10.1177/097215090700900106

Chauhan, S.P., \& Chauhan, D. (2009). Are you on the verge of obsolescence? Indian Journal of Industrial Relations, 44(4), 646-659.

Crocker, L., \& Algina, J. (2006). Introduction to Classical and Modern Test Theory. Cengage Learning.

Cronbach, L. J., Schonemann, P., \& McKie, D. (1965). Alpha coefficients for stratified-paralel tests. Educational and Psychological Measurement, 25, 291-312. https://doi.org/10.117 7/001316446502500201

Cronbach, L. J. (1984). Essentials of Psychological Testing (4th ed). Harper Row.

Çokluk, Ö., Şekercioğlu, G., \& Büyüköztürk, Ş. (2014). Sosyal Bilimler Iç̧in Çok Değişkenli İstatistik SPSS ve LISREL Uyglamalarl [Multivariate Statistics for Social Sciences: SPSS and LISREL Applications]. Pegem Akademi.

DeMars, C. (2010). Item Response Theory. Oxford University Press.

Embretson, S.E., \& Reise, S.P. (2000). Item Response Theory for Psychologists. Lawrence Erlbaum Associates.

Field, A. (2009). Discovering Statistics Using SPSS (3rd ed.). Sage Publications Ltd.

Fossum, J. A., Arvey, R.D., Paradise, C.A., \& Robbins, N. E. (1986). Modeling the Skills Obsolescence Process: A Psychological/Economic Integration, Academy of Management Review, 11(2), 362-374.

Hambleton, R. K., \& Swaminathan, H. (1985). Item Response Theory: Principles and Applications. Kluwer Nijhoff Publishing.

Jones, E., Chonko, L.B., \& Roberts, J.A. (2003). Sales for obsolescence: Perceptions from sales and marketing executives of individual, organizational, and enviornmental factors. Industrial Marketing Management, 33, 439-456.

Knight, P. (1998). Professional obsolescence and continuing professional development in higher education, Innovations in Education and Teaching International, 35(3), 248-256. https://doi.org/10.1080/1355800980350309

MacNeill, N., \& Cavanagh, R. (2006). Principals' pedagogic obsolescence: re-assessing what is important in schools. Curriculum and Leadership Journal, 4(29). http://www.curricul um.edu.au/leader/principals pedagogic obsolescence:_re-assessing wh, 15968.html?iss ueID $=10421$

Millı̂ Eğitim Bakanlığı (MEB) Eğitim Kurumları Yöneticilerinin Atama ve Yer Değiştirmelerine İlişkin Yönetmelik. [Regulation on Appointment and Relocation of Educational Institutions Administrators.] (2009, Ağustos 3). Resmi Gazete (Say1 27318). https://www.resmigazete.gov.tr/eskiler/2009/08/20090813-2.htm

Mohan, V., Chauhan, S.P., \& Chauhan, D. (2001). Are you aware how your personality effects your behavior? Global Business Review, 2(2), 289-304. https://doi.org/10.1177/0972150 $\underline{90100200209}$

Murillo, P. (2011). Human capital obsolescence: some evidence for Spain, International Journal of Manpower, 32(4), 426-445. https://doi.org/10.1108/01437721111148540

Pazy, A. (1994). Cognitive Schemata of Professional Obsolescence, Human Relations, 47(10), 1167.

Pazy, A. (1996). Concept and career-stage differentiation in obsolescence research. Journal of Organizational Behavior, 17(1), 59-78.

Rothman, R.A., \& Perrucci, R. (1971). Vulnerability to Knowledge Obsolescence: Among Professinals, The Sociological Quarterly, 12, 147-138.

Shaffer, J. D. (1969). On institutional obsolescence and innovation- Background for Professional dialogue on public policy. American Journal of Agricultureal Economics, 51(2), 245-267. 
Shearer, R., \& Steger, J. A. (1975). Manpower Obsolescence: A New Definition and Emprical Investigation of Personal Variables, Academy of Managment Journal, 18, 263- 275.

Sorensen, J. B., \& Stuart, T. E. (2000). Aging, obsolescence, and organizational innovation. Administrative Science Quarterly, 45(1), 81-112.

Tan, Ş. (2009). Misuses of KR-20 and Cronbach's alpha reliability coefficients. Journal of Education and Science, 34(152), 101-112.

Tang, K. (1996). Polytomous Item Response Theory (IRT) Models and Their Applications in Large-Scale Testing Programs: Review of Literature. Educational Testing Service.

Todman, J., \& Dugard, P. (2007). Approaching multivariate statistics: an introduction for psychology. Psychology Press.

Toner, P. (2011), Workforce Skills and Innovation: An Overview of Major Themes in the Literature, OECD Science, Technology and Industry Working Papers, 2011/1. OECD Publishing. https://doi.org/10.1787/5kgkdgdkc8tl-en

van Loo, J., Grip, A., \& Steur, M. (2001). Skills obsolescence: causes and cures. International Journal of Manpower, 22(1/2), 121-138.

Wandera, D. B. (2014). The threat of obsolescence: teaching and learning responding to technology. Technology, Pedagogy and Education, 24(2), 279-281. https://doi.org/10.10 $\underline{\text { 80/1475939X.2014.913533 }}$

Warmington, A. (1974). Obsolescence As An Organizational Phenomenon, The Journal of Management Studies, 11 (2), 96-114.

Yürekli, H. (2010). The Relationship Between Parameters from Some Polytomous Item Response Theory Models. (Unpublished Master Thesis). The Florida State University, USA. http://purl.flvc.org/fsu/fd/FSU migr etd-1104 


\section{APPENDIX}

The items and the dimensions of the scale developed to determine the Professional and Organizational Obsolescence levels of primary, secondary and high school principals are given below (Turkish version of the POS).

\begin{tabular}{|c|c|c|c|c|c|}
\hline \multicolumn{6}{|r|}{ Mesleki Eskimişlik Ölçeği } \\
\hline \multicolumn{6}{|c|}{ F1: Mesleki Gelişime Açık Olmak } \\
\hline \multirow[t]{3}{*}{ M24 } & \multicolumn{5}{|c|}{ Sizin belirleyeceğiniz bir zaman aralığında eğitim almak } \\
\hline & Çok etkili & & & & Hiç etkili değil \\
\hline & 5 & 4 & 3 & 2 & 1 \\
\hline \multirow[t]{3}{*}{ M25 } & \multicolumn{5}{|c|}{ Mesleğinizle ilgili kitap ve dergileri okumak } \\
\hline & Çok etkili & & & & Hiç etkili değil \\
\hline & 5 & 4 & 3 & 2 & 1 \\
\hline \multirow[t]{3}{*}{ M26 } & \multicolumn{5}{|c|}{$\begin{array}{l}\text { Mesleğinizle ilgili Sivil Toplum Kuruluşları (Eğitim Yönetimi Derneği vb.) toplantılarına } \\
\text { katılmak }\end{array}$} \\
\hline & Çok etkili & & & & Hiç etkili değil \\
\hline & 5 & 4 & 3 & 2 & 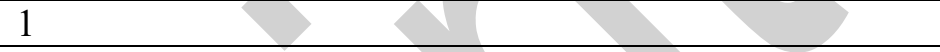 \\
\hline \multirow[t]{3}{*}{ M27 } & \multicolumn{5}{|c|}{ Beş yıl sonrası için mesleğinizle ilgili planlama yapma } \\
\hline & Çok etkili & & & & Hiç etkili değil \\
\hline & 5 & 4 & 3 & 2 & 1 \\
\hline \multirow[t]{3}{*}{ M38 } & \multicolumn{5}{|c|}{$\begin{array}{l}\text { Kurumunuzda mesleki becerileri artıracak bir gelişim planının olması sizin kendinizi } \\
\text { geliștirmenizi ne oranda motive eder? }\end{array}$} \\
\hline & Çok fazla & & & & Hiç \\
\hline & 5 & 4 & 3 & 2 & 1 \\
\hline \multirow[t]{3}{*}{ M39 } & \multicolumn{5}{|c|}{$\begin{array}{l}\text { Sizin kaydettiğiniz mesleki gelişim kurumumuz tarafından takdir edilmesi sizi ne oranda } \\
\text { motive eder? }\end{array}$} \\
\hline & Çok fazla & & & & Hiç \\
\hline & 5 & 4 & 3 & 2 & 1 \\
\hline \multirow[t]{3}{*}{ M40 } & \multicolumn{5}{|c|}{$\begin{array}{l}\text { Mesleğinizi daha cazip hale getirmeye yönelik değişiklikler sizin mesleki gelişiminizi ne } \\
\text { oranda etkiliyor? }\end{array}$} \\
\hline & Çok fazla & & & & Hiç \\
\hline & 5 & 4 & 3 & 2 & 1 \\
\hline \multirow[t]{3}{*}{ M47 } & \multicolumn{5}{|c|}{$\begin{array}{l}\text { Bir üst yöneticinizin sizin becerilerinizi nasıl geliştirebileceğiniz konusunda öneriler getirmesi } \\
\text { sizin becerilerinizi ne oranda geliştirir? }\end{array}$} \\
\hline & Çok fazla & & & & Hiç \\
\hline & 5 & 4 & 3 & 2 & 1 \\
\hline \multirow[t]{3}{*}{ M48 } & \multicolumn{5}{|c|}{ Kurumu içi eğitim programları } \\
\hline & Çok etkili & & & & Hiç etkili değil \\
\hline & 5 & 4 & 3 & 2 & 1 \\
\hline M49 & \multicolumn{5}{|c|}{ Meslekle ilgili kurum dışı eğitim programları } \\
\hline & Çok etkili & & & & Hiç etkili değil \\
\hline & 5 & 4 & 3 & 2 & 1 \\
\hline M50 & \multicolumn{5}{|c|}{ Diğer kurumlara kendi kurumu adına ziyarette bulunmak } \\
\hline & Çok etkili & & & & Hiç etkili değil \\
\hline & 5 & 4 & 3 & 2 & 1 \\
\hline M52 & \multicolumn{5}{|c|}{ İș bașinda problem çözme } \\
\hline & Çok etkili & & & & Hiç etkili değil \\
\hline & 5 & 4 & 3 & 2 & 1 \\
\hline M53 & \multicolumn{5}{|c|}{ Kurumunuz tarafindan düzenlenen ya da desteklenen seminer ve konferanslara katılma } \\
\hline & Çok etkili & & & & Hiç etkili değil \\
\hline & 5 & 4 & 3 & 2 & 1 \\
\hline M54 & Sizin mesleki gelişim & içi & $\mathrm{nol}$ & uştu & rulmuş bir çalışma grubuna katılmanız \\
\hline & Çok etkili & & & & Hiç etkili değil \\
\hline
\end{tabular}




\begin{tabular}{|c|c|c|c|c|c|}
\hline & 5 & 4 & 3 & 2 & 1 \\
\hline M55 & \multicolumn{5}{|c|}{ Mesleki anlamda ilginizi çeken bir konuda bireysel ya da ortak araştırma yapmak } \\
\hline & Çok etkili & & & & Hiç etkili değil \\
\hline & 5 & 4 & 3 & 2 & 1 \\
\hline M56 & \multicolumn{5}{|c|}{ Diploma/sertifika programlarına (Örneğin lisansüstü programlar) katılmak } \\
\hline & Çok etkili & & & & Hiç etkili değil \\
\hline & 5 & 4 & 3 & 2 & 1 \\
\hline M57 & \multicolumn{5}{|c|}{$\begin{array}{l}\text { Kurum gelişimi çalışmalarında (örneğin, müfredat geliştirme grubunda, okul gelişim ekibinde) } \\
\text { görev alma }\end{array}$} \\
\hline & Çok etkili & & & & Hiç etkili değil \\
\hline & 5 & 4 & 3 & 2 & 1 \\
\hline M58 & \multicolumn{5}{|c|}{ Kendinizi geliștirme etkinlikleri mesleğinizi etkili olarak yürütmeniz için ne kadar önemlidir? } \\
\hline & Çok önemli & & & & Hiç önemli değil \\
\hline & 5 & 4 & 3 & 2 & $\mathrm{~S}$ \\
\hline M59 & \multicolumn{5}{|c|}{ Kendini geliştirmeye yönelik etkinlikleri sizin kariyer gelişiminiz için ne kadar önemlidir? } \\
\hline & Çok önemli & & & & Hiç önemli değil \\
\hline & 5 & 4 & 3 & 2 & 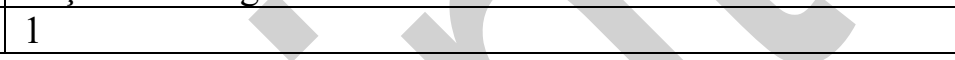 \\
\hline M60 & \multicolumn{5}{|c|}{$\begin{array}{l}\text { Yönetimde Bilgi ve İletişim Teknolojilerini Kullanma becerilerinin öğretilmesi sizin işinizi } \\
\text { etkili olarak yürütmenize ne oranda katkı sağlar? }\end{array}$} \\
\hline & Çok katk1 sağlar & & & & Hiç katk1 sağlamaz \\
\hline & 5 & 4 & 3 & 2 & 8 \\
\hline M61 & \multicolumn{5}{|c|}{$\begin{array}{l}\text { Çalışanların mesleki gelişim ihtiyaçlarının belirlenmesi çalışanların kendilerini geliştirmelerin } \\
\text { ne kadar önemlidir? }\end{array}$} \\
\hline & Çok önemli & & & & Hiç önemli değil \\
\hline & 5 & 4 & 3 & 2 & 1 \\
\hline M62 & \multicolumn{5}{|c|}{$\begin{array}{l}\text { Kurumunuzun, sizin veya diğer personelin mesleki alandaki zayıf yönlerini iyileştirmeye } \\
\text { yönelik gelişim planı oluşturmaları sizin kariyer gelişiminizde ne kadar önemlidir? }\end{array}$} \\
\hline & Çok önemli & & & & Hiç önemli değil \\
\hline & 5 & 4 & 3 & 2 & 1 \\
\hline M63 & \multicolumn{5}{|c|}{$\begin{array}{l}\text { Kurumunuzun, size meslekî gelişim etkinliklerine katılım imkânını sağlaması ne kadar } \\
\text { önemlidir? }\end{array}$} \\
\hline & Çok önemli & & $\bar{z}$ & Y & Hiç önemli değil \\
\hline & 5 & 4 & 3 & 2 & 1 \\
\hline \multicolumn{6}{|c|}{ F2: Meslekte İş Yetenek Uyumu } \\
\hline M1 & \multicolumn{5}{|c|}{ Şu anda sahip olduğunuz mesleki bilgi yaptığınız iş için ne kadar uygun? } \\
\hline & Çok uygun & & & & Uygun değil \\
\hline & $>$ & 4 & 3 & 2 & 1 \\
\hline M2 & \multicolumn{5}{|c|}{ Sahip olduğun bilgiyi yaptı̆̆ınız işle karşılaştırdığınızda nasıl görüyorsunuz? } \\
\hline & $\begin{array}{r}\text { İşin gerektirdiğinin } \\
\text { üstünde }\end{array}$ & & & & İşin gerektirdiğinin altında \\
\hline & 5 & 4 & 3 & 2 & 1 \\
\hline M3 & \multicolumn{5}{|c|}{ SSu anda sahip olduğunuz becerilerin yaptığınız iș ile uygunluk derecesi nedir? } \\
\hline & Çok uygun & & & & Hiç uygun değil \\
\hline & 5 & 4 & 3 & 2 & 1 \\
\hline M4 & \multicolumn{5}{|c|}{$\begin{array}{l}\text { Sahip olduğunuz becerileri yaptığınız işin gerektirdikleriyle karşılaştırdığınızda nasıl } \\
\text { görüyorsunuz? }\end{array}$} \\
\hline & $\begin{array}{r}\text { İşin gerektirdiğininin } \\
\text { üstünde }\end{array}$ & & & & İşin gerektirdiğinin altında \\
\hline & 5 & 4 & 3 & 2 & 1 \\
\hline M5 & \multicolumn{5}{|c|}{ Şu andaki işinizde mesleki becerilerinizden/yeteneklerinizden ne oranda yararlanılıyor? } \\
\hline & Çok fazla & & & & Hiç \\
\hline & 5 & 4 & 3 & 2 & 1 \\
\hline
\end{tabular}




\begin{tabular}{|c|c|c|c|c|c|}
\hline & Çok yüksek & & & & Çok düşük \\
\hline & 5 & 4 & 3 & 2 & 1 \\
\hline M11 & \multicolumn{5}{|c|}{ Genel olarak, işinizle ilgili bilgi/beceri öğrenme yeteneğinizi nasıl görüyorsunuz? } \\
\hline & Çok yüksek & & & & Çok düşük \\
\hline & 5 & 4 & 3 & 2 & 1 \\
\hline M12 & \multicolumn{5}{|c|}{ Öğrenme yeteneğiniz son beș yılda ne oranda değiști? } \\
\hline & Çok gelişti & & & & Hiç gelişmedi \\
\hline & 5 & 4 & 3 & 2 & 1 \\
\hline \multicolumn{6}{|c|}{ F3: Mesleki Gelişimde Örgütsel Destek } \\
\hline M28 & \multicolumn{5}{|c|}{ Kurumunuz kendinizi geliștirmenize yönelik eğitim almanızı kolaylaştırıyor mu? } \\
\hline & Çok Fazla & & & & Hiç \\
\hline & 5 & 4 & 3 & 2 & 1 \\
\hline M29 & \multicolumn{5}{|c|}{$\begin{array}{l}\text { Kurumunuzdaki politikalar, sizin daha ileri bir düzeyde eğitim almanızı ne oranda teşvik } \\
\text { ediyor? }\end{array}$} \\
\hline & Çok Fazla & & & & Hiç \\
\hline & 5 & 4 & 3 & 2 & -8 \\
\hline M30 & \multicolumn{5}{|c|}{ Kurumunuz kendi yönetici personelinin uzun süreli kariyer planlamasını ne oranda yapıyor? } \\
\hline & Çok Fazla & & & & Hiç \\
\hline & 5 & 4 & 3 & 2 & 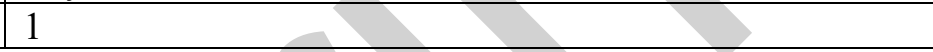 \\
\hline M31 & \multicolumn{5}{|c|}{ Yüksek performans kurumunuz tarafindan ne oranda ödüllendiriliyor? } \\
\hline & Çok Fazla & & & & Hiç \\
\hline & 5 & 4 & 3 & 2 & $\mathrm{~L}$ \\
\hline M35 & \multicolumn{5}{|c|}{ Kurumunuz sizi daha yenilikçi olmanız konusunda ne oranda cesaretlendiriyor? } \\
\hline & Çok Fazla & & & & Hiç \\
\hline & 5 & 4 & 3 & 2 & 1 \\
\hline M36 & \multicolumn{5}{|c|}{$\begin{array}{l}\text { Size göre, işinize ilgili olsun veya olmasın, bir üst amiriniz geliş̧iminize ne kadar ilgi } \\
\text { gösteriyor? }\end{array}$} \\
\hline & Çok Fazla & & & & Hiç \\
\hline & 5 & 4 & 3 & 2 & 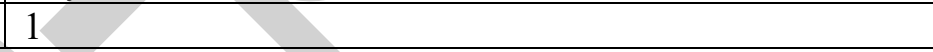 \\
\hline M37 & \multicolumn{5}{|c|}{$\begin{array}{l}\text { Kurumunuzda yöneticilerin mesleki ilerlemelerinin belirlenmesi, yöneticilerin kendilerini } \\
\text { geliștirmelerini ne oranda sağlar? }\end{array}$} \\
\hline & Çok Fazla & & 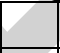 & 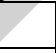 & Hiç \\
\hline & 5 & 4 & 3 & 2 & 1 \\
\hline \multicolumn{6}{|c|}{ F4: Mesleki Tükenmișlik } \\
\hline M19 & \multicolumn{5}{|c|}{$\begin{array}{l}\text { Yaşadığınız duygusal sorunlar (stres, hayal kırıklığı vb.) sizin mesleki gelişiminizi ne oranda } \\
\text { etkilemektedir? }\end{array}$} \\
\hline & Çok Fazla & 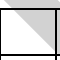 & $\nabla$ & & Hiç \\
\hline & 5 & 4 & 3 & 2 & 1 \\
\hline M20 & \multicolumn{5}{|c|}{ Sağlık durumunuz sizin mesleğinizi etkili yapmada ne oranda etkilidir? } \\
\hline & Çok Fazla & & & & Hiç \\
\hline & 5 & 4 & 3 & 2 & 1 \\
\hline M21 & \multicolumn{5}{|c|}{$\begin{array}{l}\text { Sizin çalışma biçiminizin kurumunuzun çalışma biçimiyle uyumsuzluğu, sizin iş } \\
\text { performansınızı nasıl etkiler? }\end{array}$} \\
\hline & Çok Fazla & & & & Hiç \\
\hline & 5 & 4 & 3 & 2 & 1 \\
\hline M22 & \multicolumn{5}{|c|}{$\begin{array}{l}\text { Kurumunuzun yönetim biçiminin sizin kişiliğinizle çatışması sizin iş performansınızı ne } \\
\text { oranda etkiler? }\end{array}$} \\
\hline & Çok Fazla & & & & Hiç \\
\hline & 5 & 4 & 3 & 2 & 1 \\
\hline M23 & \multicolumn{5}{|c|}{$\begin{array}{l}\text { Yeteneğinizin üstünde kurumunuzda size bir görev verilmesi sizin performansınızı ne oranda } \\
\text { etkiler? }\end{array}$} \\
\hline & Çok Fazla & & & & Hiç \\
\hline & 5 & 4 & 3 & 2 & 1 \\
\hline
\end{tabular}




\begin{tabular}{|c|c|c|c|c|c|}
\hline \multirow[t]{2}{*}{ M41 } & \multicolumn{5}{|c|}{ Kurumunuzun amaçlarının belirsiz olması, sizin işinize karşı tutumunuzu ne oranda etkiliyor? } \\
\hline & Çok Fazla & & & & Hiç \\
\hline & 5 & 4 & 3 & 2 & 1 \\
\hline \multirow[t]{3}{*}{ M42 } & \multicolumn{5}{|c|}{$\begin{array}{l}\text { Sizin üstünüzün sizin bilgi ve becerinizdeki eskimişliği önemsememesi sizin kendinizi } \\
\text { geliştirmenizi ne oranda etkiliyor? }\end{array}$} \\
\hline & Çok Fazla & & & & Hiç \\
\hline & 5 & 4 & 3 & 2 & 1 \\
\hline \multirow[t]{3}{*}{ M43 } & \multicolumn{5}{|c|}{$\begin{array}{l}\text { Kurumunuzda sizin işinizle ilgili performansınıza yönelik dönüt mekanizmasının yetersiz } \\
\text { olması sizin ișinizi etkili yapmanızı ne oranda etkiler? }\end{array}$} \\
\hline & Çok Fazla & & & & Hiç \\
\hline & 5 & 4 & 3 & 2 & 1 \\
\hline M44 & \multicolumn{5}{|c|}{$\begin{array}{l}\text { Kurumunuzda, etkili olacağınız bir göreve atanmamış olmanız sizlerin bilgi ve becerilerinizi } \\
\text { geliștirmenizi ne oranda etkiler? }\end{array}$} \\
\hline & Çok Fazla & & & & Hiç \\
\hline & 5 & 4 & 3 & 2 & 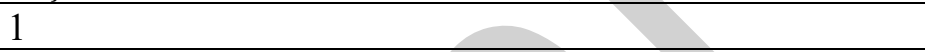 \\
\hline
\end{tabular}

